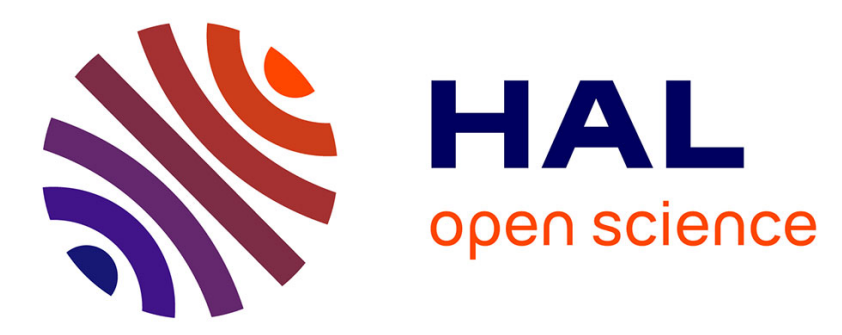

\title{
Changes in functional biodiversity in an invaded freshwater ecosystem: the Moselle River
}

Simon Devin, Jean-Nicolas Beisel, Philippe Usseglio-Polatera, Jean-Claude Moreteau

\section{- To cite this version:}

Simon Devin, Jean-Nicolas Beisel, Philippe Usseglio-Polatera, Jean-Claude Moreteau. Changes in functional biodiversity in an invaded freshwater ecosystem: the Moselle River. Hydrobiologia, 2005, 542 (1), pp.113-120. 10.1007/s10750-004-8771-6 . hal-01726784

\section{HAL Id: hal-01726784 \\ https://hal.univ-lorraine.fr/hal-01726784}

Submitted on 8 Mar 2018

HAL is a multi-disciplinary open access archive for the deposit and dissemination of scientific research documents, whether they are published or not. The documents may come from teaching and research institutions in France or abroad, or from public or private research centers.
L'archive ouverte pluridisciplinaire HAL, est destinée au dépôt et à la diffusion de documents scientifiques de niveau recherche, publiés ou non, émanant des établissements d'enseignement et de recherche français ou étrangers, des laboratoires publics ou privés. 


\title{
Changes in functional biodiversity in an invaded freshwater ecosystem: the Moselle River.
}

\author{
Simon DEVIN ${ }^{1 *}$, Jean-Nicolas BEISEL ${ }^{1}$, Philippe USSEGLIO-POLATERA ${ }^{1}$ \\ and Jean-Claude MORETEAU ${ }^{1}$
}
${ }^{1}$ Université de Metz - UFR SciFA - Laboratoire Biodiversité et Fonctionnement des
Ecosystèmes - Campus Bridoux, Av. du Gén. Delestraint, 57070 Metz, FRANCE

Key words: invasive species, freshwater macroinvertebrates, bio/ecological traits, functional diversity, biomonotony concept

\footnotetext{
* Author to whom correspondence should be sent

Telephone: $+33(0) 387378431$

E-mail: devin@ sciences.univ-metz.fr

Fax: $+33(0) 387378423$
}

This paper has not been submitted elsewhere, in either identical or similar form, nor will it be during the first three months after its submission to Hydrobiologia. 


\begin{abstract}
The spread of non-indigenous species and the decline of autochthonous ones are leading to a homogenization of freshwater fauna in terms of systematic units, but the functional consequences are poorly documented. We studied the peculiar case of the lower, French section of the Moselle River where 20 invertebrate species have been introduced since 1854, with a rate increasing exponentially with time. Dredge sampling performed in 1994, 1996, 2000 and 2001 at four sampling stations allowed for an evaluation of faunal changes in terms of composition, structure and function. During this period, no structural changes were recorded in spite of multiple, new and successful introductions. The evaluation of functional modifications was based on a typology of taxa exhibiting homogeneous biological/ecological traits. Functional diversity, measured as the diversity of taxa distribution among functional groupings, revealed a significant increase between 1994/1996 and 2000/2001 because those species that were over-represented during the former period reached more equilibrated densities during the latter. The major, indirect implications of these functional changes are discussed.
\end{abstract}




\section{Introduction}

The fauna in freshwater ecosystems is being modified at unprecedented rates by human activities, resulting in a decline of local species and a spread of exotic or invasive ones. Navigable sectors of large rivers are the most affected or the most threatened aquatic ecosystems due to their multiple uses and the resulting stresses. While many studies have focused on the characteristics of successful invaders (Williamson, 1996; Ricciardi \& Rasmussen, 1998; Kolar \& Lodge, 2001), the impact of multiple introductions on recipient ecosystems is still poorly documented (Van der Velde et al., 2000).

In this context, the main, inter-related aspects of faunal changes in a community composition, structure and functional diversity - have to be evaluated. Composition (i.e. a list of species) and taxonomic structure (usually described with biotic indices or distribution models) are often studied, but the functional diversity of a given community, much more difficult to evaluate, is scarcely approached. However, an evaluation of functional modifications can be based on a recent, innovative functional classification of benthic macroinvertebrates assembling taxa with similar suites of biological and ecological traits in increasingly larger faunal groups (Usseglio-Polatera et al., 2001). Species belonging to a given group may be considered as 'functionally redundant' for the major processes occurring in the ecosystem, considering that the functional effects of a taxon are output variables or consequences of its combination of traits and use of resources (Rosenfeld, 2002). From this viewpoint, three different factors were taken into account in the analysis of 22 biological and ecological traits performed by Usseglio-Polatera et al. (2001): (i) morphological and physiological features of taxa related to ecological processes (described with traits such as 'feeding habits', 'respiration mode' or 'maximal size'), (ii) demographic characteristics of 
populations (traits such as 'life cycle duration' or 'potential number of reproduction cycles per year'), and (iii) ecological preferences influencing the functionally-relevant distribution of a taxon (traits such as 'longitudinal distribution' or 'salinity preferendum'). If each taxon in a given community is replaced by its functional group, the assessment of 'group diversity' has the potential to provide a useful, simple measure of that community's functional diversity. In this context, we aimed at analysing recent faunal changes in the Moselle River, in terms of composition, structure and functioning, following a succession of uncontrolled introductions of macroinvertebrates. After a short description of the invasion pattern we focused on the consequences of repeated introductions on functional diversity.

\section{Materials and methods}

\section{Study sites}

The lower part of the Moselle River is canalized to allow for a high shipping traffic between the Rhine, the Meuse and the Saône catchments. The large number of weirs induces the presence of several diverted stretches flowing parallel to the canalized one. The present study was carried out at four sites (Figure 1): Dieulouard, Metz, Cattenom and Sierck-les-Bains, covering approximately $100 \mathrm{~km}$ of the lower Moselle. The sites were chosen because they represent the main environmental conditions encountered along the river, and are typical of the canalized sections (except for the Metz sampling site located $400 \mathrm{~m}$ upstream from a navigable section). All four sampling sites were characterised by a mineral substratum ranging from coarse sand to pebbles. 


\section{Sampling protocol}

Benthic samples were collected in 1994, 1996, 2000 and 2001, at a depth of about 4 m., by dredging the bottom in a direction perpendicular to one transect. On each transect, the left side, the right side (each one at 4 metres from the bank) and the middle of the river were sampled.. This method is designed to collect the main populations living in the channel and thus representing the major part of the macrobenthic biomass. On each sampling occasion, the surface of the sampled area was evaluated according to (1) the length of the dredge draught estimated from the volume of dredged material, (2) the dredge section and (3) the sediment depth (Berly, 1989). Macroinvertebrate densities were then expressed per square metre (Table I for detailed information on the sampling protocol).

The samples collected in 1994, 1996 and 2000 were preserved in $4 \%$ formaldehyde, but those from 2001 were frozen $\left(-20^{\circ} \mathrm{C}\right)$ shortly $(<4 \mathrm{~h})$ after collection. Macroinvertebrates were sorted, identified and counted under a stereomicroscope. Most taxa were identified to the genus level, except for some exotic species identified to species level, and Diptera identified only at family level. Oligochaeta and Nematoda were recorded as such.

\section{Statistical analyses}

The functional diversity of each community was calculated using the Shannon-Weaver index (Shannon \& Weaver, 1963) according to the distribution of individuals (and taxa) among functional groups (Usseglio-Polatera et al., 2001). The significance of temporal variations in diversity indices was tested using the non-parametric Friedman ANOVA $(\alpha=0.05)$ test. The assessment of changes in functional diversity was performed using the Mann-Withney test $(\alpha=0.05)$. 


\section{Results}

Biological invasion is a common phenomenon in the Moselle River, with 20 species of macroinvertebrates introduced since 1854 , most of them belonging to Crustacea and Mollusca (Table II). Seven exotic species were recorded before the first half of the $20^{\text {th }}$ century and thirteen thereafter. The trend in cumulative numbers of successful introductions is best described by an exponential function (Figure 2), which explains $7 \%$ more variance than a linear one.

The taxonomic composition of the fauna reveals an increase in the relative abundances of autochthonous individuals between 1994 (34.2\%) and 2000 (67.1\%), followed by a severe decrease in 2001 (12.1\%), due mainly to a decrease in relative abundances of 'insects' and 'other' autochthonous taxa (Cnidaria, Achaeta, Nematoda and Oligochaeta). Conversely, an increase in 'other' exotic species can be observed, linked to the introduction of the freshwater Polychaeta Hypania invalida. A decline in exotic molluscs occurred in relation with a massive decrease in Dreissena polymorpha between 1994 and 1996. Finally, only one autochthonous crustacean Asellus aquaticus, present at Dieulouard, still remained in the Moselle River in 2001, while the proportion of exotic crustaceans increased with the establishment of two new species, Dikerogammarus villosus and Jaera istri (Figure 3).

During the period from 1994 to 2001, the major, structural characteristics of macrobenthic communities did not change in terms of taxonomic richness or taxonomic diversity (nonparametric Friedman ANOVA, $p=0.34$ for taxonomic richness and $\mathrm{p}=0.054$ for taxonomic diversity; Figure 4). Conversely, in terms of functional characteristics, the functional diversity increased significantly between 1994-1996 and 2000-2001 ( $\mathrm{p}=0.005$, Figure 5). During the period from 1994 to 1996, functional diversity was very low due to the high relative abundance of taxa (such as D. polymorpha and C. curvispinum) belonging to the same 
bio/ecological group $(\zeta)$. In 2000-2001, a decrease in the dominance of this group was observed (Simpson dominance, $\lambda=0.82$ in $1994, \lambda=0.66$ in 2001; Mann Withney test, $p=0.04$ ), that was not counterbalanced by the establishment of several new exotic species also belonging to the group $\zeta(D$. villosus, J. istri, H. invalida). The major decrease in $D$. polymorpha density in the Moselle River (Bachmann et al., 2001) seemed to play a key role in this pattern. We can also note that the increase in functional diversity was far more significant upstream than downstream, even with a decrease in the section furthest downstream at Sierck. Conversely, the other functional groups became increasingly represented along the temporal gradient (Figure 6), involving the increase in functional diversity.

\section{Discussion}

The exponential trend in the cumulative, successfully-introduced species over time in the Moselle River highlights an accelerating accumulation of exotic species during the last decade. This increase may also reflect a growing interest in biological invasions and increased knowledge of freshwater fauna. Otherwise, several hypotheses can be proposed potentially to explain this increasing rate over time: (1) an increase of propagule pressure due to the increasing development of shipping traffic, (2) a process of facilitative interactions which favors new exotic species from the same biogeographic area than previously successful introduced species (Simberloff \& Von Holle, 1999) and (3) a decline in biotic resistance following the alteration of the environment and the decline of autochthonous species. Most introduced species in the Moselle River belong to Crustacea and Mollusca, a fact already observed in other freshwater ecosystems (Morton, 1997; Van der Velde et al., 2000; Grigorovich et al., 2002). Such taxonomic clumping of invaders can result in an over- 
representation of specific traits which enhance transport, dispersal, establishment and/or massive development in a recipient ecosystem.

Most of the major, recent invasive species in lowland sections of large, western-european rivers belong to the $\zeta$ group, including organisms with a unique combination of features (large-size, asexual reproduction, thermophilous, polysaprobic, affinity for silt and sand, mainly filter or deposit feeders, burrowers or permanently attached), which distinguish them clearly from taxa of other functional groups (Usseglio-Polatera et al., 2001, unpublished results).

Assessing the functional consequences of a given introduction is a stimulating, challenging part of biological invasion research. Functional diversity translates the bio/ecological response of organisms to multiple environmental constraints. Its interest lies in the condensed expression of major ecological processes such as nutrient cycles or energy flows throughout different ecosystem compartments. This method, as applied to the Moselle River, is based on the study of groups of taxa with similar suites of bio/ecological traits. This approach highlights functional changes over a very short period of time following a succession of successful introductions. In 1994-1996, functional diversity was very low, illustrating the strong degradation of the river community after the demographic explosion of several new exotic species introduced in the beginning of the 1990's (Bachmann et al., 1995). Recent temporal variations in the density of exotic species probably led to the more equilibrated faunal structure observed in 2000-2001, due in particular to the decline of Dreissena polymorpha (Bachmann et al., 2001), which exhibited a very high density in the Moselle during the 1994-1996 period. As a counterpoint to the decrease in relative abundances of group $\zeta$, an increase in relative abundance of groups $\beta$ and $\gamma 2$ was observed. This phenomenon allowed a better representation of various ecological functions in the ecosystem, and contributed to the increase in the community's functional diversity between 1994-1996 
and 2000-2001. The migratory corridor of invasive species, following the downstreamupstream gradient, could explain the pattern of changes in functional diversity within the four sections. For example, J. istri, one of the most recent invaders, was only present in Sierck in 2001, thus increasing the relative abundance of the $\zeta$ group and decreasing the functional diversity on this section.

Functional diversity takes into account the relative abundances of taxa and gives the best condensed representation of the diversity of bio/ecological trait combinations in an ecosystem. The use of evenness to track faunal changes also allows to highlight functional modifications in benthic communities before the total disappearance of a set of species with the same bio/ecological profile is observed (Chapin et al., 2000).

An increase in functional diversity following several, successful invasions is not so surprising. Indeed, species introductions can increase community diversity locally, whereas they are always involved in a decrease in diversity at a global scale (Sax \& Gaines, 2003). However, even at a local scale, this increase is often counterbalanced by the unpredictable impact of non indigenous species on the ecosystem, such as non-endemic pathogens. For example, the presence of Orconectes limosus, the American crayfish introduced in 1978 in the Moselle River, spread the crayfish plague (Aphanomyces astaci) which infested the very susceptible indigenous crayfish Astacus astacus (Van der Velde et al., 2000). Moreover, most introduced species are distributed worldwide and have achieved the status of cosmopolitan species. Navigated sectors of large rivers in Europe are more and more homogeneous both in terms of physical attributes and in terms of macrobenthic fauna. This homogenization of freshwater fauna, already reported for fishes (Rahel, 2002) and birds (McKinney \& Lockwood, 1999), could lead to a decrease in the resilience of ecosystems exposed to disturbance. The spread of cosmopolitan species involves a decrease in the diversity of bio/ecological traits combinations in communities. As a result, the range of potential responses of a given community to 
disturbance becomes narrower. The community is destabilized and weakened, and the ecological impacts it suffers intensify (Olden et al., in press).

Acknowledgements - The authors wish to thank V. Bachmann for contribution to data collection from 1994 and 1996, P. Wagner for efficient assistance during field work and Anna Matheny-Cartier for revision of the manuscript. This study was supported by the French Ministry of Ecology and Sustainable Development, as part of the 2003-2005 INVABIO Biological Invasions Program.

\section{References}

Bachmann, V., 2000. Dynamique spatio-temporelle d'espèces invasives, particulièrement Corbicula spp. et Dreissena polymorpha (Mollusca : Bivalvia) en hydrosystème fluvial : évolution des populations et effets de l'artificialisation sur les peuplements macrobenthiques. Ph. D. Thesis, University of Metz. 229p.

Bachmann, V., Beisel, J.N., Usseglio-Polatera, P. and Moreteau, J.C. 2001. Decline of Dreissena polymorpha in the River Moselle: biotic and abiotic key factors involved in dynamics of invasive species. - Archiv für Hydrobiologie 151: 263-281.

Bachmann, V., Cegielka, E., Wagner, P., Usseglio-Polatera, P. and Moreteau, J.C. 1995. Establishment of the amphipod Corophium curvispinum and the asiatic clam Corbicula sp. in the French part of the River Moselle. - Hydroécologie appliquée 7: 185-190.

Berly, A., 1989. Distribution spatio-temporelle des peuplements macrobenthiques prélevés par dragage dans une station du Haut-Rhône. Ph. D. Thesis, University of Lyon I. 309p. 
Chapin, F. S. III, Zavaleta, E. S., Eviners, V. T., Naylor, R. L., Vitousek, P. M., Reynolds, H. L., Hooper, D. U., Lavorel, S., Sala, O.E., Hobbie, S. E., Mack, M. C. and Díaz, S. 2000. Consequences of changing biodiversity. - Nature 405: 234-242.

Devin, S., Beisel, J. N., Bachmann, V. and Moreteau, J. C. 2001. Dikerogammarus villosus (Amphipoda: Gammaridae): Another invasive species newly established in the Moselle River and French hydrosystems. - Annales de Limnologie-International Journal of Limnology 37: 21-27.

Dhur, G. and Massard, J. A. 1995. Etude historique et faunistique des Invertébrés immigrés ou introduits dans la Moselle luxembourgoise et ses affluents. - Bulletin de la Société Naturelle luxembourgeoise 127-156.

Grigorovich, I. A., MacIsaac, H. J., Shadrin, N. V. and Mills, E. L. 2002. Patterns and mechanisms of aquatic invertebrate introductions in the Ponto-Caspian region. Canadian Journal of Fisheries and Aquatic Sciences 59: 1189-1208.

Kolar, C. S. and Lodge, D. M. 2001. Progress in invasion biology: predicting invaders. Trends in Ecology and Evolution 16: 199-204.

McKinney, M. L. and Lockwood, J. L. 1999. Biotic homogenization: a few winners replacing many losers in the next mass extinction. - Trends in Ecology and Evolution 14: 450453.

Morton, B. 1997. The aquatic nuisance species problem: a global perspective and review. - In: D'Itri, F. (ed.) Zebra Mussels and Aquatic Nuisance Species. Ann Arbor Press, Chelsea, Michigan, pp. 1-53.

Olden, J. D., LeRoy Poff, N., Douglas, M. R., Douglas, M. E. and Fausch, K. D. Ecological and evolutionary consequences of biotic homogenization. - Trends in Ecology and Evolution 19: 18-24. 
Rahel, F. J. 2002. Homogenization of freshwater fauna. - Annual Review of Ecology and Systematics 33: 291-315.

Ricciardi, A. \& Rasmussen, J. B. 1998. Predicting the identity and impact of future biological invaders: a priority for aquatic resource management. - Canadian Journal of Fisheries and Aquatic Sciences 55: 1759-1765.

Rosenfeld, J. S. 2002. Functional redundancy in ecology and conservation. - Oikos 98: 156162.

Sax, D. F. and Gaines, S. D. 2003. Species diversity: from global decreases to local increases. - Trends in Ecology and Evolution 18: 561:566.

Shannon, C. E. and Weaver, W. 1963. The Mathematical Theory of Communication. University of Illinois Press, Urbana. 117 p.

Simberloff, D. and Von Holle, B. 1999. Positive interactions of non indigenous species: invasional meltdown? - Biological Invasions 1:21-32.

Usseglio-Polatera, P., Richoux, P., Bournaud, M. and Tachet, H. 2001. A functional classification of benthic macroinvertebrates based on biological and ecological traits: application to river condition assessment and stream management. - Archiv für Hydrobiologie Suppl. 139: 53-83.

Van der Velde, G., Rajagopal, S., Kelleher, B., Musko, I.B. and bij de Vaate, A. 2000. Ecological impacts of crustacean invaders: general considerations and examples from the river Rhine. - Crustacean Issues 12: 3-33.

Williamson, M. 1996. Biological Invasions. - Chapman \& Hall, London 
Table I. Basic data for the four sites at each sampling date.

\begin{tabular}{|c|c|c|c|c|c|c|c|c|}
\hline \multirow{2}{*}{$\begin{array}{l}\text { Sampling } \\
\text { date }\end{array}$} & \multirow[t]{2}{*}{ Station } & \multirow{2}{*}{$\begin{array}{c}\text { Number } \\
\text { of } \\
\text { samples }\end{array}$} & \multirow{2}{*}{$\begin{array}{l}\text { Surface } \\
\left(\mathrm{m}^{2}\right)\end{array}$} & \multirow{2}{*}{$\begin{array}{l}\text { Mean total } \\
\text { density } \\
\text { (ind. } m^{-2} \text { ) }\end{array}$} & \multicolumn{2}{|c|}{$\begin{array}{l}\text { Individual number } \\
\text { (ind. } \mathrm{m}^{-2} \text { ) }\end{array}$} & \multicolumn{2}{|c|}{ Taxa number } \\
\hline & & & & & Exotic & Autochthonous & Exotic & Autochtonous \\
\hline \multirow{4}{*}{1994} & Sierck & 3 & 0.232 & 26791 & 9711 & 17081 & 4 & 15 \\
\hline & Cattenom & 3 & 0.046 & 272456 & 135503 & 136952 & 3 & 19 \\
\hline & Metz & 3 & 0.293 & 209292 & 190685 & 18607 & 4 & 22 \\
\hline & Dieulouard & 3 & 0.084 & 169077 & 110021 & 59056 & 3 & 20 \\
\hline \multirow{3}{*}{1996} & Cattenom & 1 & 0.144 & 17325 & 270 & 17055 & 5 & 14 \\
\hline & Metz & 3 & 0.526 & 5292 & 4204 & 1088 & 5 & 20 \\
\hline & Dieulouard & 3 & 0.938 & 12280 & 9444 & 2836 & 6 & 27 \\
\hline \multirow{4}{*}{2000} & Sierck & 3 & 0.238 & 7306 & 3601 & 3705 & 6 & 23 \\
\hline & Cattenom & 3 & 0.155 & 12959 & 3213 & 9745 & 7 & 18 \\
\hline & Metz & 3 & 0.114 & 19679 & 7390 & 12290 & 8 & 22 \\
\hline & Dieulouard & 3 & 0.352 & 5158 & 642 & 4516 & 6 & 16 \\
\hline \multirow{4}{*}{2001} & Sierck & 3 & 0.310 & 26103 & 25865 & 238 & 8 & 7 \\
\hline & Cattenom & 3 & 0.669 & 11547 & 11138 & 409 & 8 & 14 \\
\hline & Metz & 3 & 0.747 & 4300 & 3465 & 834 & 8 & 14 \\
\hline & Dieulouard & 3 & 0.498 & 32122 & 24633 & 7489 & 8 & 22 \\
\hline
\end{tabular}


Table II. Introduced species in the French part of the Moselle River. (1: Dhur \& Massard, 1995; 2: Bachmann, 2000; 3: Devin et al., 2001). Functional groups were reported from Usseglio-Polatera et al., 2001, and from unpublished results.

\begin{tabular}{|c|c|c|c|c|c|}
\hline Species & Systematic unit & $\begin{array}{l}\text { Introduction } \\
\text { date }\end{array}$ & Origin & $\begin{array}{l}\text { Functional } \\
\text { group }\end{array}$ & Reference \\
\hline Dreissena polymorpha & Mollusca: Bivalvia & 1854 & Ponto-Caspian & $\zeta$ & 1 \\
\hline Orchestia cavimana & Crustacea: Amphipoda & $\begin{array}{l}\text { First half of the } \\
20^{\text {th }} \text { century }\end{array}$ & $\begin{array}{l}\text { Ponto-Caspian and } \\
\text { Mediterranean }\end{array}$ & & 1 \\
\hline Echinogammarus berilloni & Crustacea: Amphipoda & $\begin{array}{l}\text { First half of the } \\
20^{\text {th }} \text { century }\end{array}$ & $\begin{array}{l}\text { South-Western } \\
\text { Europe }\end{array}$ & $\zeta$ & 1 \\
\hline Atyaephyra desmarestii & Crustacea: Decapoda & 1920s & Mediterranean & $\gamma 2$ & 1 \\
\hline Physa acuta & Mollusca: Gasteropoda & $1920 \mathrm{~s}$ & Mediterranean & $\gamma 1$ & 1 \\
\hline Branchiura sowerbyi & Oligochaeta & $1930 \mathrm{~s}$ & South-Eastern Asia & $\zeta$ & 1 \\
\hline Lithoglyphus naticoides & Mollusca: Gasteropoda & 1931 & Ponto-Caspian & $\gamma 1$ & 1 \\
\hline Dugesia tigrina & Turbellaria: Tricladida & $1950 \mathrm{~s}$ & North America & $\gamma 2$ & 1 \\
\hline Potamopyrgus jenkinsi & Mollusca: Gasteropoda & 1976 & New-Zealand & $\zeta$ & 1 \\
\hline Craspedacusta sowerbyi & Cnidaria: Hydrozoa & About 1978 & Asia & $\gamma 2$ & 1 \\
\hline Orconectes limosus & Crustacea: Decapoda & 1978 & North America & $\gamma 2$ & 1 \\
\hline Cordylophora caspia & Cnidaria: Hydrozoa & 1987 & Ponto-Caspian & $\zeta$ & 1 \\
\hline Gammarus tigrinus & Crustacea: Amphipoda & 1991-1992 & North America & $\beta$ & 1 \\
\hline $\begin{array}{l}\text { Chelicorophium } \\
\text { curvispinum }\end{array}$ & Crustacea: Amphipoda & 1994 & Ponto-Caspian & $\zeta$ & 2 \\
\hline Corbicula fluminea & Mollusca: Bivalvia & 1994 & Asia & $\zeta$ & 2 \\
\hline Corbicula fluminalis & Mollusca: Bivalvia & 1994 & Asia & $\zeta$ & 2 \\
\hline Dikerogammarus villosus & Crustacea: Amphipoda & 1998 & Ponto-Caspian & $\zeta$ & 3 \\
\hline Limnomysis benedeni & Crustacea: Mysidacea & 2001 & Ponto-Caspian & & $\begin{array}{c}\text { personal } \\
\text { observation }\end{array}$ \\
\hline Jaera istri & Crustacea: Isopoda & 2001 & Ponto-Caspian & $\zeta$ & $\begin{array}{c}\text { personal } \\
\text { observation }\end{array}$ \\
\hline Hypania invalida & $\begin{array}{l}\text { Polychaeta: } \\
\text { Ampharetidae }\end{array}$ & 2001 & Ponto-Caspian & $\zeta$ & $\begin{array}{c}\text { personal } \\
\text { observation }\end{array}$ \\
\hline
\end{tabular}


Figure captions

Figure 1: Location of the four sampling sites along the Moselle River.

Figure 2: Cumulative number of introduced species in the Moselle River since the mid-19th century. The final number of exotic species (19) is lower than that presented in the table II (20) because an introduced gammarid (E. berilloni) disappeared from the river before 2001. Linear and exponential adjustments were applied to describe the trend.

Figure 3: Relative abundances of the main taxonomic groups in the Moselle River sections studied between 1994 and 2001. See table I for the abundances.

Figure 4: Variation of the mean ( \pm standard deviation) taxonomic richness per sample (a) and diversity (b) in the Moselle River section studied between 1994 and 2001. See Table I for the number of samples per year.

Figure 5: Functional diversity of four Moselle River sections between 1994 and 2001. (Shannon-Weaver index was calculated on distribution of individuals among functional groups defined by Usseglio-Polatera et al., 2001).

*: The Sierck station was not sampled in 1996

Figure 6: Relative abundances of functional groups (excluding the $\zeta$ group) in the benthic community of four Moselle River sections. Two groups were not shown on this graph because of their low relative abundance (see Usseglio-Polatera et al., 2001 for further details on mean bio-ecological profiles of groups). 


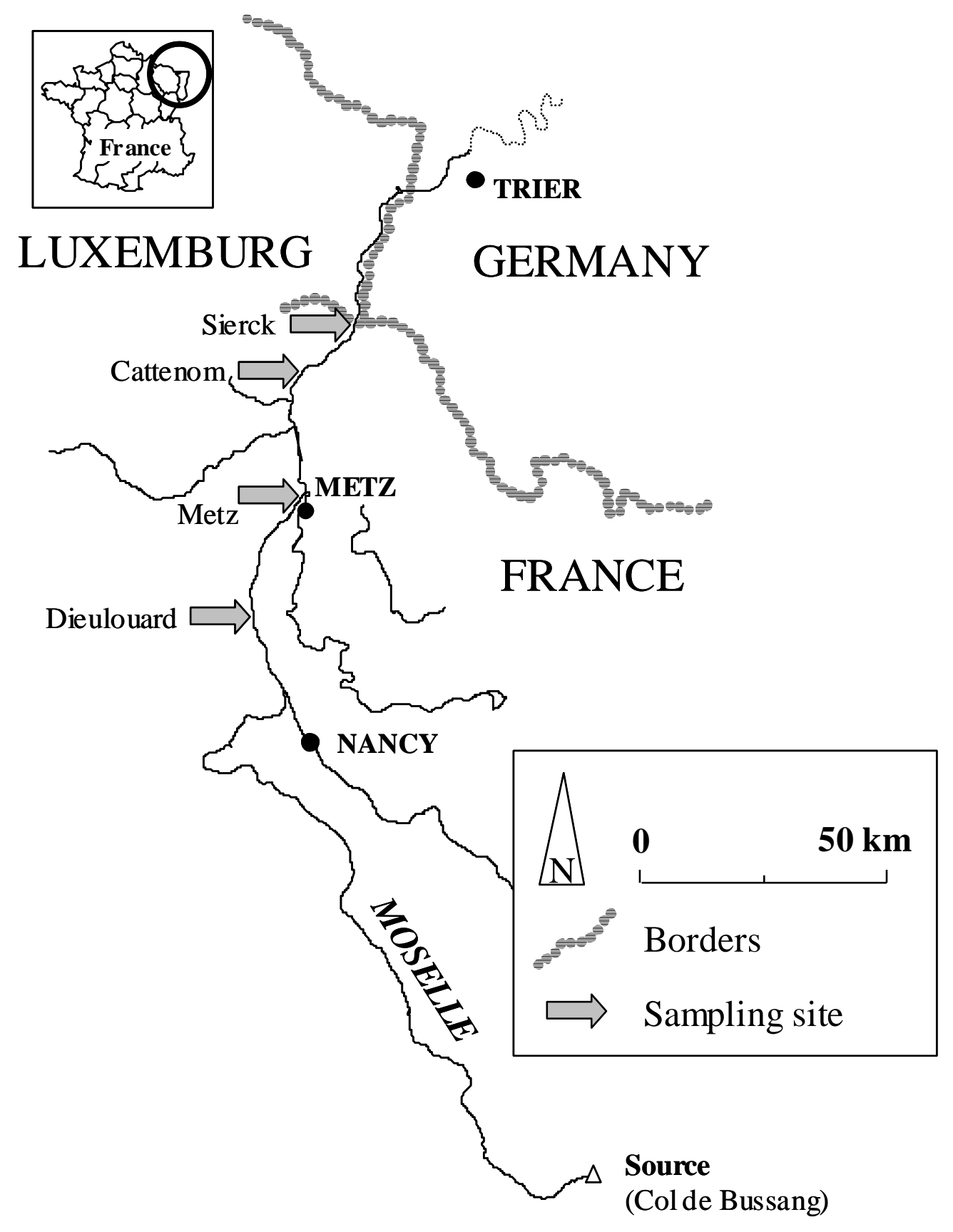

Devin et al. Figure 1. 


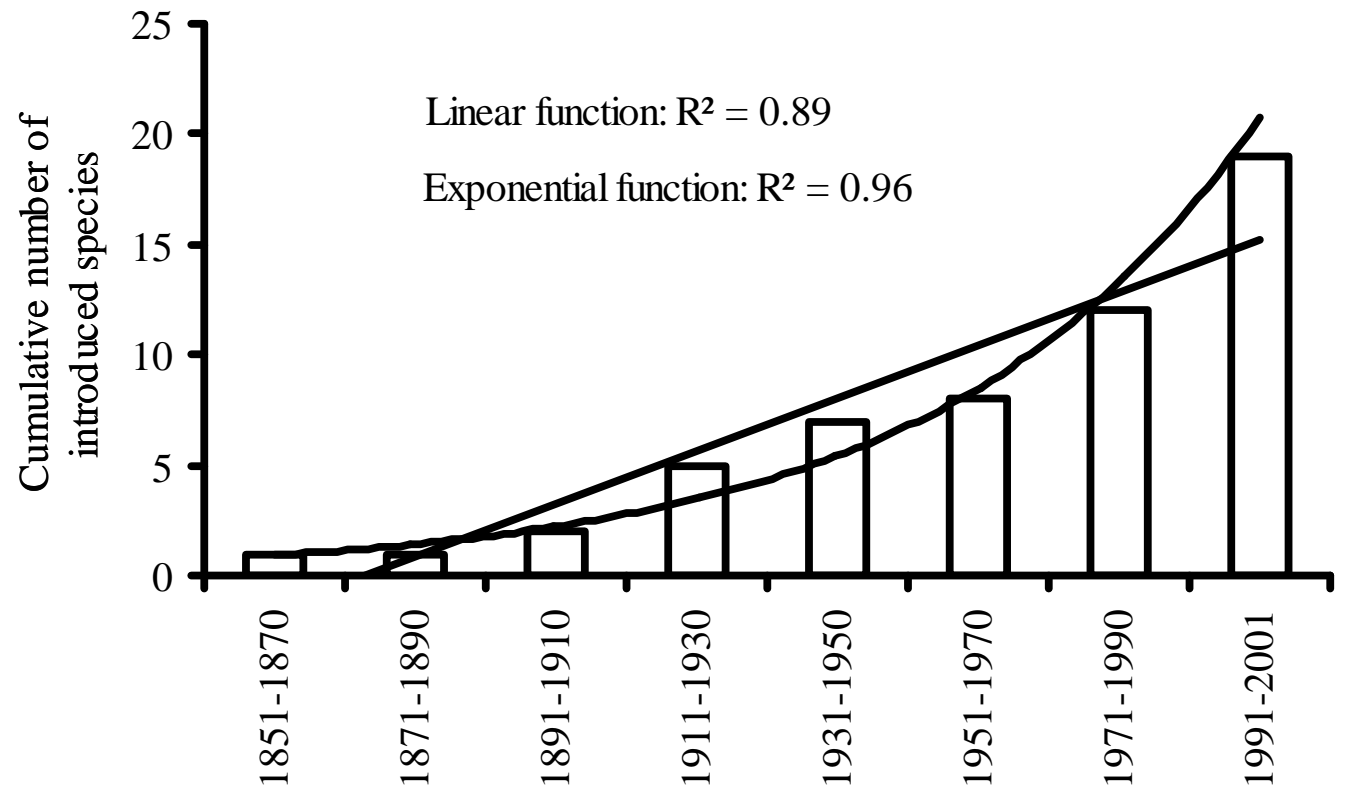

Devin et al. Figure 2. 


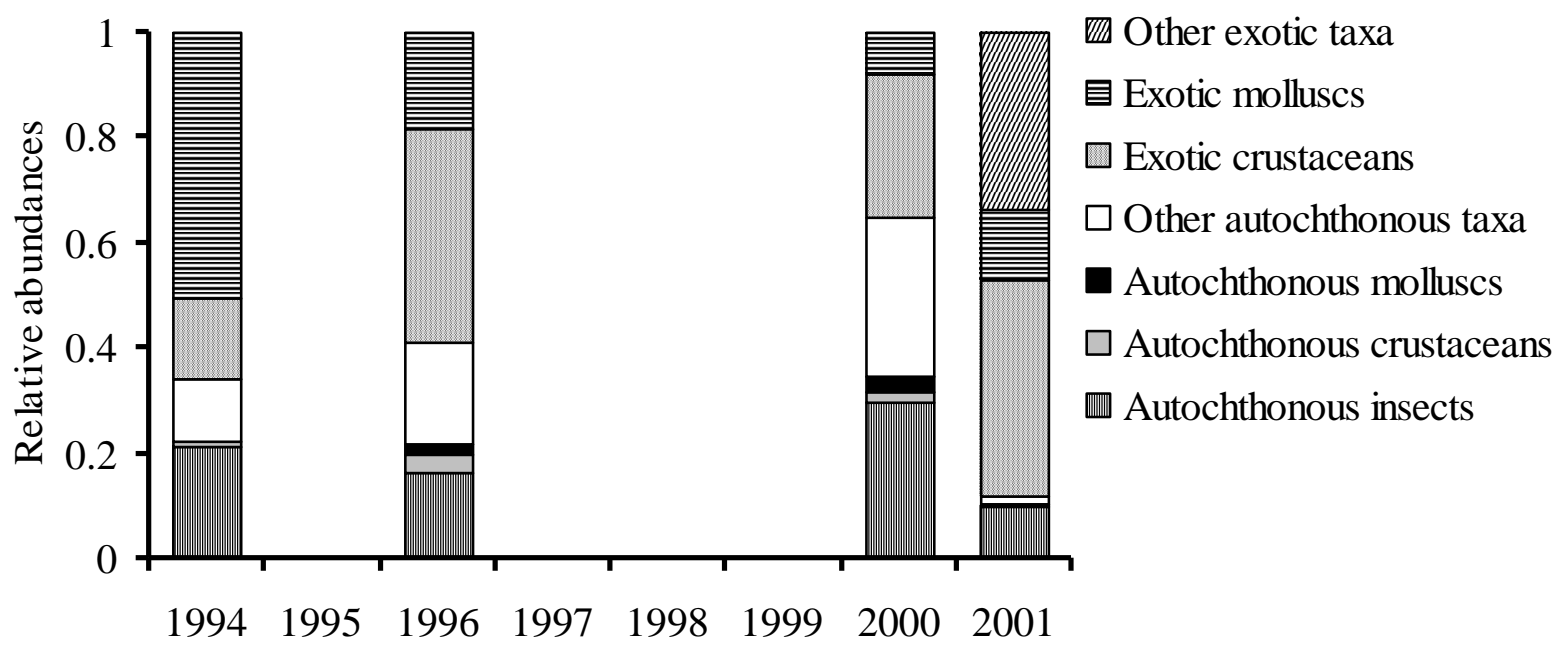

Devin et al. Figure 3. 

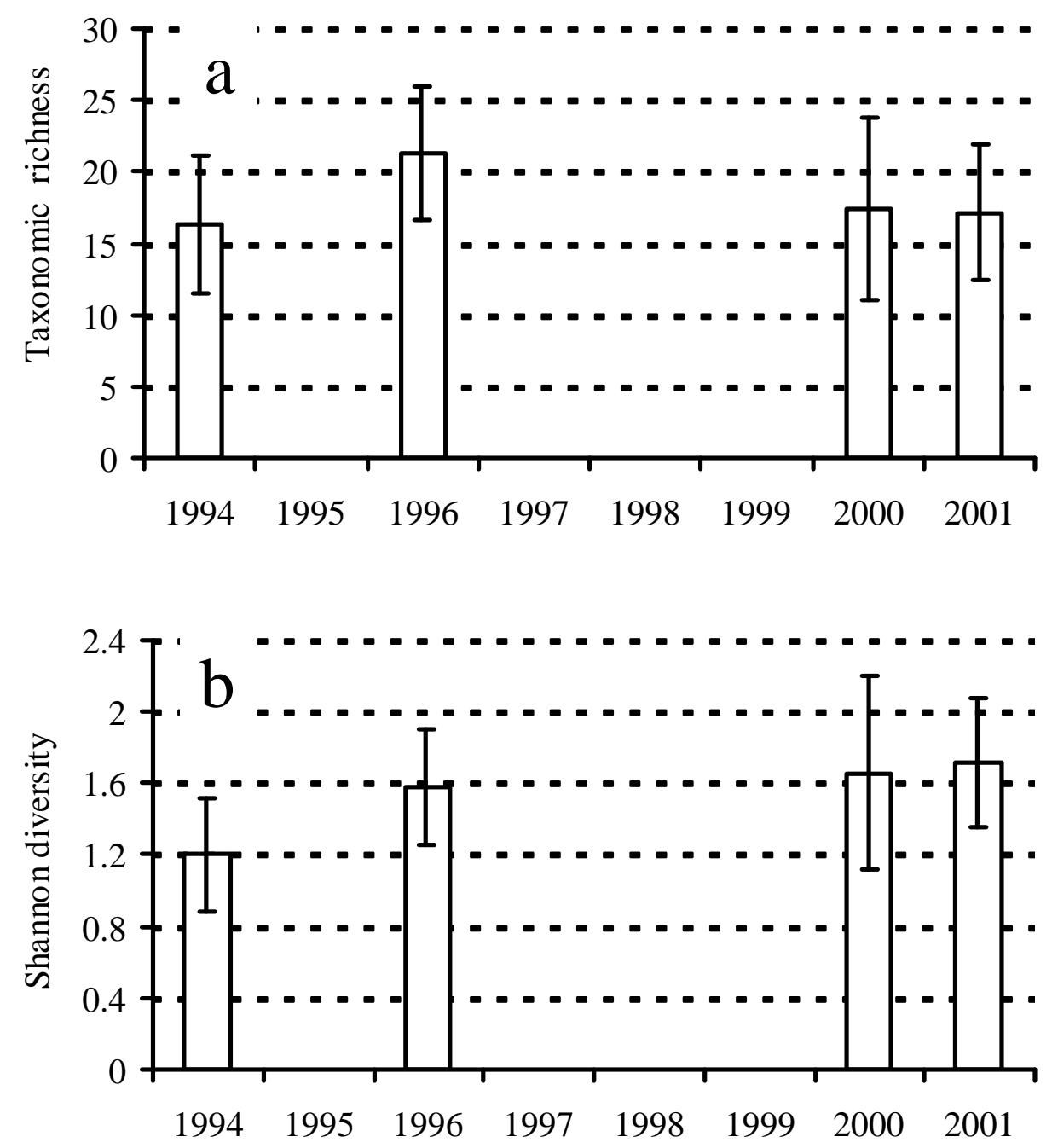

Devin et al. Figure 4. 


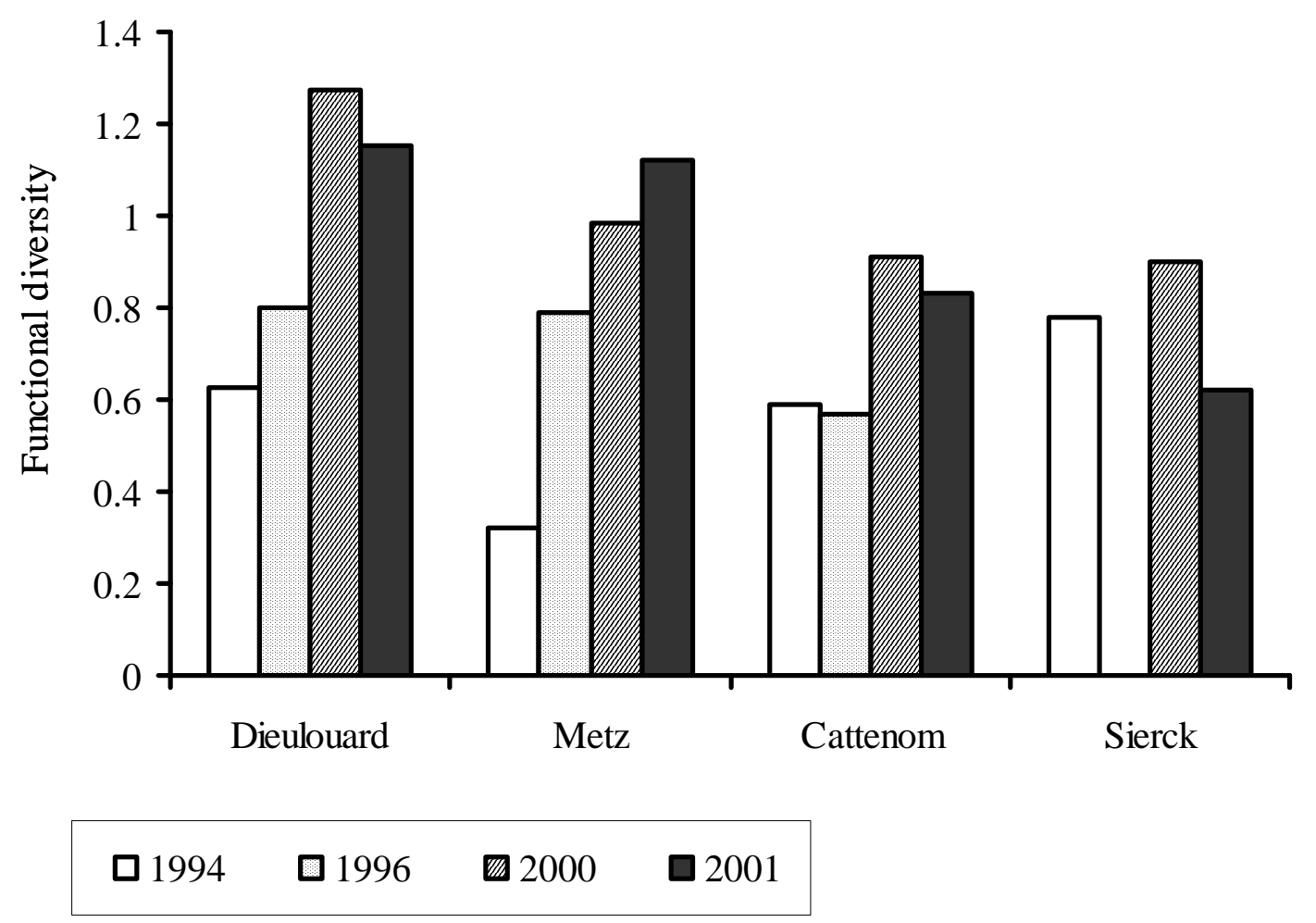

Devin et al. Figure 5. 


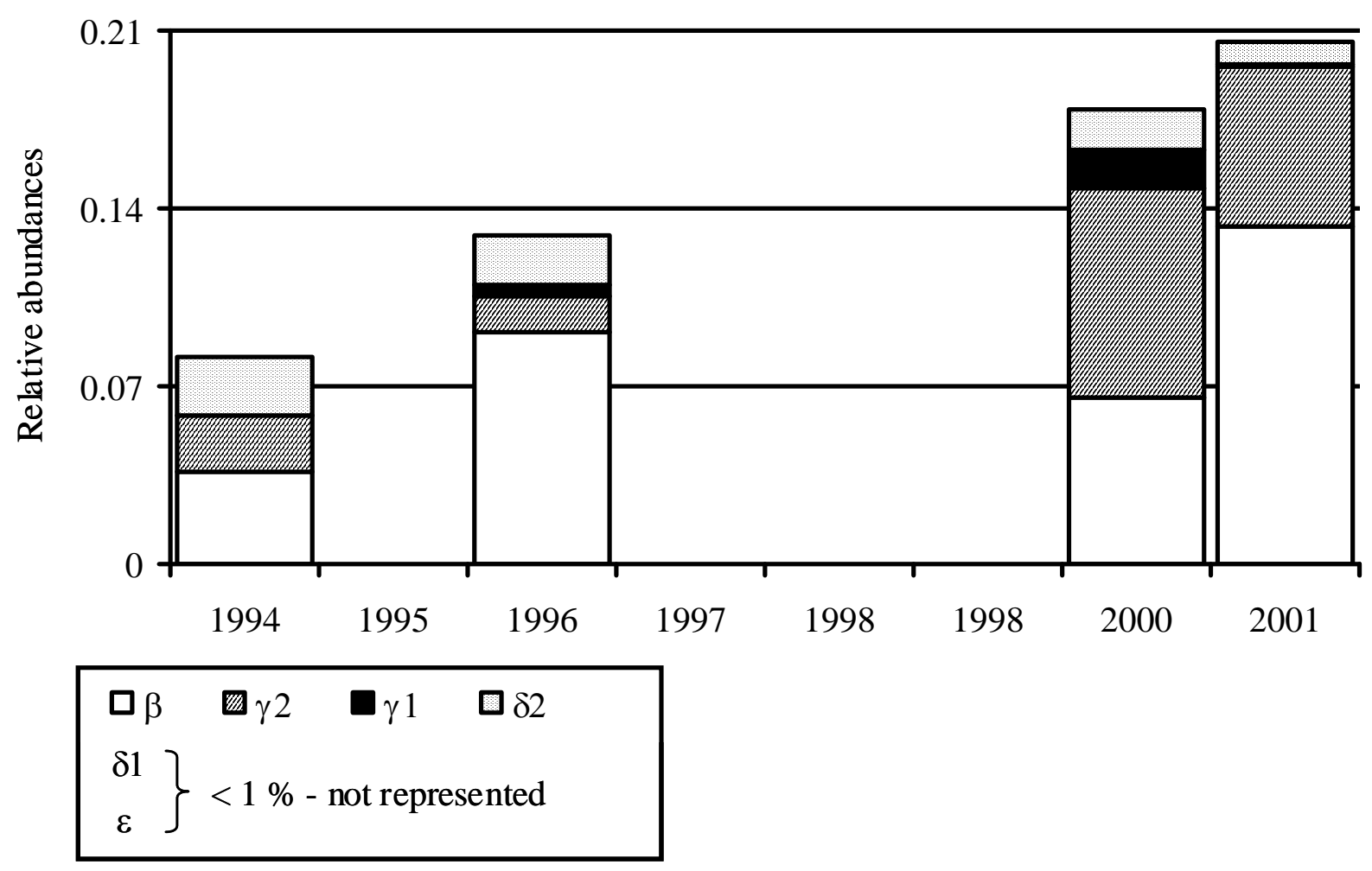

Devin et al. Figure 6. 